\title{
PENGARUH PENDAPATAN DAERAH TERHADAP PERTUMBUHAN EKONOMI DI WILAYAH SARBAGITA PROVINSI BALI
}

\author{
Lily Kusumawati ${ }^{1}$ \\ I Gusti Bagus Wiksuana ${ }^{2}$ \\ ${ }^{1,2}$ Fakultas Ekonomi dan Bisnis Universitas Udayana, Bali, Indonesia \\ e-mail: lilykusumawti@gmail.com
}

\begin{abstract}
ABSTRAK
Tujuan penelitian ini mengetahui pengaruh Pendapatan Asli Daerah (PAD), Dana Alokasi Umum (DAU), Dana Alokasi Khusus (DAK) dan Dana Bagi Hasil (DBH) terhadap pertumbuhan ekonomi di wilayah Sarbagita Provinsi Bali. Penelitian ini dilakukan di wilayah Sarbagita Provinsi Bali menggunakan metode sampling jenuh dalam penentuan sampel dengan populasi dan sampel adalah wilayah Kota Denpasar, Kabupaten Badung, Kabupaten Gianyar dan Kabupaten Tabanan pada tahun 2012 - 2016. Pengumpulan data dilakukan melalui teknik observasi nonpartisipan. Analisis data dilakukan menggunakan analisis deskriptif daan regresi linier berganda. Berdasarkan hasil penelitian menunjukkan bahwa Pendapatan Asli Daerah (PAD) dan Dana Alokasi Khusus (DAK) berpengaruh positif terhadap pertumbuhan ekonomi di wilayah Sarbagita Provinsi Bali. Sedangkan Dana Alokasi Umum (DAU) dan Dana Bagi Hasil (DBH) berpengaruh negatif terhadap pertumbuhan ekonomi di wilayah Sarbagita Provinsi Bali.
\end{abstract}

Kata kunci: pertumbuhan ekonomi, pendapatan daerah, sarbagita

\begin{abstract}
The purpose of this research is to know the effect of Pendapatan Asli Daerah (PAD), Dana Alokasi Umum (DAU), Special Allocation Fund (DAK) and Profit Sharing Fund (DBH) to economic growth in Sarbagita area of Bali Province. This research was conducted in Sarbagita area of Bali Province using saturated sampling method in determining samples with population and sample are Denpasar City, Badung, Gianyar and Tabanan regencies in 2012 - 2016. Data collection was done through nonparticipant observation technique. Data analysis was done using descriptive analysis and multiple linear regression. Based on the results of research requires that Pendapatan Asli Daerah (PAD) and Special Allocation Fund (DAK) have a positive effect on economic growth in Sarbagita area of Bali Province. While the General Allocation Fund (DAU) and DBH (Fund DBH) negatively affect the economic growth in the Sarbagita area of Bali Province.
\end{abstract}

Keywords: economic growth, regional income, sarbagita 
Lily Kusumawati, Pengaruh Pendapatan Daerah...

\section{PENDAHULUAN}

Pembangunan nasional merupakan proses pengembangan keseluruhan sistem penyelenggaraan negara untuk mewujudkan tujuan nasional yang tercantum dalam pembukaan UUD 1945. Semakin besar tingkat pembangunan suatu negara mengindikasikan negara tersebut semakin maju dan berkembang (Dewi, 2015). Ada beberapa indikator yang menentukan keberhasilan pembangunan nasional, misalnya pertumbuhan ekonomi, struktur ekonomi, indeks kualitas hidup, urbanisasi dan indeks pembangunan manusia, kesehatan, pendidikan (Parsiyo dan Widya, 2013). Pertumbuhan ekonomi merupakan salah satu indikator penting untuk menganalisis sebuah pembangunan nasional yang terjadi di suatu negara dan menjadi perhatian terutama pemerintah.

Pertumbuhan ekonomi merupakan suatu proses peningkatan produksi barang dan jasa dalam segala aktivitas perekonomian di suatu negara pada periode tertentu. Pada dasarnya aktivitas perekonomian adalah suatu proses penggunaan faktor-faktor produksi untuk menghasilkan output, maka proses ini pada gilirannya akan menghasilkan suatu aliran balas jasa terhadap faktor produksi yang dimiliki oleh masyarakat. Pertumbuhan ekonomi menunjukkan sejauh mana aktivitas perekonomian akan menghasilkan tambahan pendapatan masyarakat pada suatu periode tertentu. Ada beberapa hal yang dapat mempengaruhi pertumbuhan ekonomi diantaranya yaitu pendapatan, belanja, dan pembiayaan. Diantara ketiga komponen tersebut, pendapatan merupakan indikator yang sangat penting dalam meningkatkan pertumbuhan ekonomi, maka dari itu pertumbuhan ekonomi memacu pemerintah daerah memaksimalkan pemberdayaan segenap 
sumber daya potensial yang ada, serta membuka peluang kerja sama masyarakat (sebagai investor dan/atau pekerja) guna menciptakan lapangan pekerjaan baru yang akan mempengaruhi perkembangan kegiatan ekonomi dalam daerah tersebut.

Indonesia sebagai salah satu negara berkembang mempunyai pertumbuhan ekonomi yang dapat dikatakan dalam kondisi yang baik di tengah kondisi ekonomi global yang sedang lesu. Dilansir dalam sindonews.com, Mentri Keuangan Sri Mulyani menyatakan bahwa pertumbuhan ekonomi Indonesia pada kuartal III tahun 2016 tumbuh 5,04 persen. Hal ini tidak terlepas dari adanya peranan pembangunan daerah yang merupakan bagian penting dari pembangunan nasional (Muchtholifah, 2010). Indonesia merupakan negara kepulauan yang terdiri dari 33 provinsi dan salah satu provinsi di Indonesia dengan tingkat pertumbuhan ekonomi yang baik adalah Provinsi Bali. Provinsi Bali merupakan salah satu daerah dengan sektor pariwisata sebagai tulang punggung utama dalam memaksimalkan pertumbuhan ekonomi daerahnya.

Pertumbuhan ekonomi daerah diukur dengan menggunakan Produk Domestik Regional Bruto (PDRB). Totalitas keseluruhan nilai barang dan jasa yang diperoleh dari seluruh kegiatan perekonomian yang dilakukan daerah disebut PDRB (Jaya dan Dwirandra, 2014:81). Perhitungan tingkat pertumbuhan ekonomi suatu daerah menggunakan PDRB atas dasar harga konstan.

Struktur perekonomian di Bali memiliki karakteristik yang berbeda dengan provinsi lainnya di Indonesia. Spesifik perekonomian Bali dibangun dengan mengandalkan sektor pariwisatanya. Pertumbuhan ekonomi Provinsi Bali yang 
positif tersebut dapat ditunjukkan melalui data PDRB Per Kapita 9 Kabupaten/Kota yang ada di Provinsi Bali tahun 2012 - 2016.

Tabel 1. Perbandingan PDRB Per Kapita Kabupaten / Kota Se-Bali Atas Harga Dasar Konstan Tahun 2010 (dalam Juta Rupiah) Tahun 2012 - 2016

\begin{tabular}{cccccccc}
\hline & Kabupaten/ & \multicolumn{9}{c}{ Tahun / Years } & Rata - \\
Ko & \begin{tabular}{c} 
Kota \\
\cline { 3 - 7 }
\end{tabular} & $\mathbf{2 0 1 2}$ & $\mathbf{2 0 1 3}$ & $\mathbf{2 0 1 4}$ & $\mathbf{2 0 1 5}$ & $\mathbf{2 0 1 6}$ & $\begin{array}{c}\text { PDRB } \\
\text { PDR }\end{array}$ \\
\hline 1 & Jembrana & 23,91 & 25,10 & 26,44 & 27,91 & 29,38 & 26,55 \\
2 & Tabanan & 24,55 & 25,95 & 27,47 & 29,02 & 30,92 & 27,59 \\
3 & Badung & 41,79 & 43,58 & 45,56 & 47,34 & 49,46 & 45,56 \\
4 & Gianyar & 25,99 & 27,50 & 29,10 & 30,65 & 32,28 & 29,10 \\
5 & Klungkung & 23,35 & 24,61 & 25,95 & 27,39 & 28,94 & 26,05 \\
6 & Bangli & 14,16 & 14,91 & 15,69 & 16,57 & 17,50 & 15,86 \\
7 & Karangasem & 18,74 & 19,79 & 20,86 & 22,00 & 23,18 & 20,93 \\
8 & Buleleng & 24,41 & 25,99 & 27,62 & 29,13 & 30,70 & 27,57 \\
9 & Denpasar & 28,23 & 29,58 & 31,01 & 32,28 & 33,76 & 30,97 \\
& Bali & $\mathbf{2 6 , 6 9}$ & $\mathbf{2 8 , 1 3}$ & $\mathbf{2 9 , 6 7}$ & $\mathbf{3 1 , 0 9}$ & $\mathbf{3 2 , 6 6}$ & $\mathbf{2 9 , 6 5}$ \\
\hline
\end{tabular}

Sumber: Badan Pusat Statistik Provinsi Bali (BPS Provinsi Bali) (diolah)

Tabel 1. menunjukkan bahwa rata-rata PDRB Provinsi Bali selama lima tahun terakhir dipimpin oleh Kabupaten Badung yaitu sebesar 45,56 juta rupiah, kemudian urutan kedua adalah Kota Denpasar sebesar 30,97 juta rupiah, urutan ketiga yaitu Kabupaten Gianyar sebesar 29,10 juta rupiah, dan disusul oleh Kabupaten Tabanan sebesar 27,59 juta rupiah. Pertumbuhan PDRB di beberapa kabupaten/kota di Provinsi Bali mengalami fluktuasi yang cukup signifikan. Fluktuasi yang terjadi menunjukkan kinerja ekonomi di beberapa kabupaten/kota masih kurang baik, hal ini membuktikan bahwa banyak kabupaten/kota di Provinsi Bali belum dapat menunjukkan perubahan yang signifikan dalam peningkatan PDRBnya, meskipun secara garis besar Provinsi Bali memiliki kontribusi dalam pertumbuhan ekonomi di Indonesia.

Keempat kabupaten/kota yaitu Kota Denpasar, Kabupaten Badung, Kabupaten Gianyar, dan Kabupaten Tabanan atau yang sering disebut wilayah 
Sarbagita merupakan lokasi pariwisata yang menjadi perhatian wisatawan domestik ataupun internasional. Oleh karena itu, wilayah Sarbagita memiliki peran yang sangat besar dalam menunjang pertumbuhan ekonomi di Provinsi Bali, akan tetapi wilayah ini mengakibatkan ketimpangan di beberapa kabupaten/kota lainnya.

Pelaksanaan otonomi daerah telah diatur dalam UU No. 9 Tahun 2015 tentang perubahan kedua atas UU No. 23 Tahun 2014 tentang Pemerintahan Daerah. Pemerintah daerah memiliki wewenang untuk menggali pendapatan dan melakukan peran alokasi secara mandiri dalam menetapkan prioritas pembangunan melalui otonomi daerah dan desentralisasi fiskal. Adanya kebijakan otonomi daerah dan desentralisasi fiskal diharapkan mampu mengurangi ketimpangan vertikal dan horizontal antar daerah dan dapat memeratakan pembangunan sesuai dengan keinginan daerah untuk mengembangkan wilayah menurut potensi daerahnya masing-masing.

Menurut UU No. 33 Tahun 2004 dalam pelaksanaan desentralisasi fiskal, Pendapatan Asli daerah (PAD), Dana Alokasi Umum (DAU), Dana Alokasi Khusus (DAK), Dana Bagi Hasil (DBH), pinjaman daerah dan lain-lain penerimaan yang sah merupakan sumber penerimaan yang digunakan untuk pendanaan pemerintah daerah. Upaya peningkatan penerimaan daerah dengan memberi perhatian kepada perkembangan PAD akan mendorong pemerintah untuk meningkatkan pertumbuhan ekonomi dan kebutuhan masyarakat. Selain itu, DBH, DAU, DAK dan bantuan keuangan dari pemerintah daerah provinsi, serta 
lain-lain pendapatan yang sah merupakan sumber penerimaan lain yang dapat digunakan untuk membiayai belanja daerah.

PAD, DAU, DAK, dan DBH merupakan bagian dari sumber keuangan pemerintah daerah. Kaitannya dengan pelaksanaan otonomi daerah pemerintah selalu melakukan peningkatan PAD, karena merupakan penerimaan dari usaha untuk membiayai penyelenggaraan pemerintah daerah. Peningkatan PAD harus berdampak pada perekonomian daerah (Maryati dan Endrawati, 2010). Secara tidak langsung pemerintah dituntut untuk meningkatkan potensi-potensi yang ada di daerahnya masing-masing agar dapat mandiri dalam melaksanakan fungsi dan memberlakukan pembiayaan seluruh kegiatan daerah.

Dari beberapa penelitian sebelumnya terdapat perbedaan hasil penelitian yang dimana menurut Setyawan (2013) bahwa DAU berpengaruh secara signifikan terhadap pertumbuhan ekonomi di Provinsi Lampung, DAK memiliki hubungan positif namun tidak signifikan secara statistik dalam mempengaruhi pertumbuhan ekonomi di Provinsi Lampung, dan sebaliknya DBH memiliki pengaruh negatif terhadap pertumbuhan ekonomi di Provinsi Lampung. Penelitian yang dilakukan Santosa (2013) menunjukkan bahwa PAD dan DAU tidak berpengaruh terhadap tingkat pertumbuhan ekonomi daerah di 33 provinsi di Indonesia, sebaliknya DAK dan $\mathrm{DBH}$ berpengaruh terhadap peningkatan pertumbuhan ekonomi daerah di 33 provinsi di Indonesia. Hasil penelitian Dewi (2015) di Kabupaten/kota di provinsi Bali tahun 2007 - 2013 juga menunjukkan bahwa DBH berpengaruh langsung terhadap pertumbuhan ekonomi, akan tetapi PAD tidak berpengaruh langsung terhadap pertumbuhan ekonomi. Berbeda 
dengan hasil penelitian Mawarni dkk. (2013) di Kabupaten dan Kota di Aceh tahun 2005 - 2011 menunjukkan bahwa PAD dan DAU berpengaruh positif signifikan terhadap pertumbuhan ekonomi di Kabupaten dan Kota di Aceh.

Hasil penelitian oleh Putri (2015) menunjukkan bahwa PAD berpengaruh positif dan signifikan terhadap pertumbuhan ekonomi, sedangkan DAU tidak berpengaruh terhadap pertumbuhan ekonomi, sedangkan hasil penelitian Panji (2016) menunjukkan bahwa DAU memiliki hubungan positif dan signifikan terhadap pertumbuhan ekonomi, sebaliknya DAK tidak berpengaruh signifikan terhadap pertumbuhan ekonomi.

Beberapa penelitian yang telah dilakukan di berbagai daerah tersebut meyakinkan bahwa pentingnya PAD, DAU, DAK dan DBH untuk dilakukan analisis guna mengetahui seberapa besar pengaruh masing-masing variabel terhadap pertumbuhan ekonomi agar nantinya mampu menyelenggarakan pembangunan daerah sesuai dengan potensi-potensi dari setiap daerah. Berdasarkan dari beberapa penelitian yang dilakukan di Provinsi Bali masih belum ada penelitian khususnya di wilayah Sarbagita. Hal tersebut mendorong peneliti untuk menggunakan wilayah Sarbagita Provinsi Bali sebagai obyek penelitian. Penelitian ini bertujuan untuk mengetahui signifikansi pengaruh Pendapatan Asli Daerah (PAD), Dana Alokasi Umum (DAU), Dana Alokasi Khusus (DAK) dan Dana Bagi Hasil (DBH) terhadap pertumbuhan ekonomi di wilayah Sarbagita Provinsi Bali.

Menurut Faridi (2011) fungsi utama desentralisasi fiskal yaitu untuk meningkatkan efisiensi sektor publik dan memberikan dampak pada pertumbuhan 
Lily Kusumawati, Pengaruh Pendapatan Daerah...

ekonomi dalam jangka panjang. Pada era otonomi daerah sekarang ini setiap daerah dituntut untuk lebih mandiri, baik dalam menjalankan pemerintahannya maupun dalam mendanai keuangan daerahnya (Taras, 2017). Menurut Saragih (2003: 82) keuangan daerah berarti segala bentuk kekayaanan milik daerah yang berhubungan dengan seluruh hak dan kewajiban daerah dalam rangka pelaksanaan pemerintahan dearah yang ada di dalam kerangka Anggaran Pendapatan dan Belanja Daerah (APBD) yang terdiri dari Pendapatan Daerah, Belanja Daerah dan Pembiayaan Daerah.

Menurut UU No. 33 Tahun 2004 pasal 1 tentang Perimbangan Keuangan Daerah Pemerintah Pusat dan Pemerintahan Daerah menyatakan bahwa Pendapatan daerah merupakan hak pemerintah daerah yang diakui sebagai penambah nilai kekayaan bersih dalam periode tahun bersangkutan. Sumber Pendapatan Daerah dalam struktur APBD terdiri dari: Pendapatan Asli Daerah (PAD) yang merupakan salah satu sumber penerimaan daerah memiliki keterkaitan dengan pertumbuhan ekonomi, dimana PAD dapat dikatakan sebagai modal yang digunakan dalam pembiayaan pembangunan daerah, Dana Perimbangan merupakan dana yang berasal dari penerimaan Anggaran Pendapatan dan Belanja Negara (APBN) dengan tujuan dialokasikan pada daerah untuk mendanai kebutuhan daerah. Menurut struktur APBD, Dana Perimbangan terdiri dari Dana Alokasi Umum (DAU), Dana Alokasi Khusus (DAK), dan Dana Bagi Hasil (DBH) dan lain-lain pendapatan daerah bertujuan memberi peluang kepada daerah untuk memperoleh pendapatan selain dari PAD dan dana perimbangan yang terdiri dari hibah dan dana darurat. 
Menurut Sukirno (2010) Pertumbuhan ekonomi didefinisikan sebagai perkembangan kegiatan dalam perekonomian yang menyebabkan barang dan jasa yang diproduksikan dalam masyarakat bertambah. Terdapat enam ciri pertumbuhan ekonomi yang berdasarkan pada produk nasional dan komponennya, yaitu: (1) Laju pertumbuhan penduduk dan produk per kapita; (2) Peningkatan produktivitas; (3) Laju perubahan struktural yang tinggi; (4) Urbanisasi; (5) Ekspansi negara maju; serta (6) Arus barang, modal dan orang antar bangsa (Kuznet, 2000).

Hubungan antara Pendapatan Asli Daerah (PAD), Dana Alokasi Umum (DAU), Dana Alokasi Khusus (DAK), dan Dana Bagi Hasil (DBH) dengan Pertumbuhan Ekonomi dapat digambarkan dalam kerangka konseptual pada Gambar 1.

\section{Gambar 1. Kerangka Konseptual Penelitian}

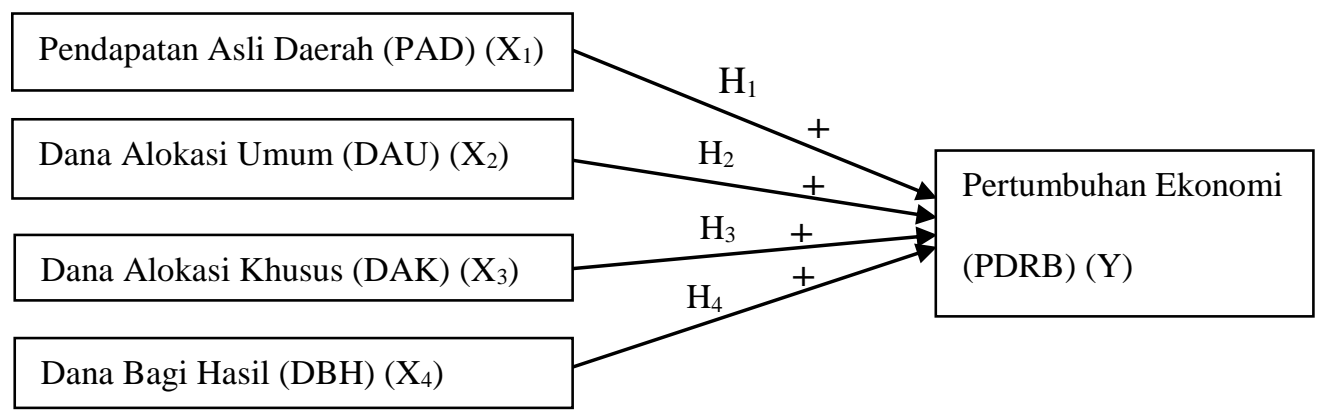

Pendapatan Asli Daerah (PAD) merupakan pendapatan daerah yang paling berkontribusi untuk menunjang pembangunan daerah dalam rangka desentralisasi. Hal tersebut didukung dengan hasil penelitian yang dilakukan oleh Mawarni dkk., (2013) dan Putri (2015) yang menyatakan bahwa Pendapatan Asli Daerah 
Lily Kusumawati, Pengaruh Pendapatan Daerah...

berpengaruh positif dan signifikan terhadap pertumbuhan ekonomi. Berdasarkan penelitian tersebut, hipotesis penelitian yang dihasilkan adalah sebagai berikut:

$\mathrm{H}_{1}$ : Pendapatan Asli Daerah (PAD) berpengaruh positif dan signifikan terhadap Pertumbuhan Ekonomi di wilayah Sarbagita Provinsi Bali.

Upaya yang dapat dilakukan untuk menanggulangi ketimpangan fiskal adalah dengan mengalokasikan dana yang bersumber dari APBN oleh pemerintah yang digunakan untuk membiayai kegiatan daerah dalam rangka otonomi. DAU seharusnya digunakan untuk membiayai belanja langsung yaitu belanja yang berhubungan dengan kesejahteraan masyarakatnya yang nantinya akan berdampak pada pertumbuhan ekonomi daerahnya masing-masing. Hal tersebut didukung dengan hasil penelitian yang dilakukan oleh Setyawan (2013), Mawarni dkk., (2013) dan Panji (2016) yang menunjukkan bahwa Dana Alokasi Umum berpengaruh secara signifikan terhadap pertumbuhan ekonomi. Berdasarkan penelitian tersebut, hipotesis penelitian yang dihasilkan adalah sebagai berikut:

$\mathrm{H}_{2}$ : Dana Alokasi Umum (DAU) berpengaruh positif dan signifikan terhadap Pertumbuhan Ekonomi di wilayah Sarbagita Provinsi Bali

Dana perimbangan lainnya yang mempunyai fungsi sebagai pelengkap disebut DAK. DAK memiliki peran dalam peningkatan pembiayaan belanja pemerintah melalui belanja modal pemerintah daerah yang akan mengalami peningkatan setiap tahunnya dan akan berdampak langsung pada pertumbuhan ekonomi daerah tersebut. Hal tersebut didukung dengan hasil penelitian oleh Setyawan (2013) yang menunjukkan bahwa DAK memiliki hubungan positif namun tidak signifikan dalam mempengaruhi pertumbuhan ekonomi. Santosa (2013) menyatakan bahwa DAK berpengaruh terhadap pertumbuhan ekonomi. 
Berdasarkan penelitian tersebut, hipotesis penelitian yang dihasilkan adalah sebagai berikut:

$\mathrm{H}_{3}$ : Dana Alokasi Khusus (DAK) berpengaruh positif dan signifikan terhadap Pertumbuhan Ekonomi di wilayah Sarbagita Provinsi Bali

Dana Bagi Hasil (DBH) digunakan untuk membiayai kebutuhan daerah dalam rangka pelaksanaan otonomi daerah dengan tujuan untuk mengurangi ketimpangan fiskal vertikal antara tingkat pemerintahan dengan cara meratakan kemampuan fiskal antar pemerintah daerah guna memacu belanja daerah dalam membiayai kegiatan-kegiatan yang berdampak pada pembangunan nasional, pencapaian infrastruktur publik, dan memacu pendapatan daerah. Hal tersebut didukung dengan hasil penelitian yang dilakukan oleh Santosa (2013) dan Dewi (2015) yang menyatakan bahwa DBH berpengaruh terhadap pertumbuhan ekonomi Berdasarkan penelitian tersebut, hipotesis penelitian yang dihasilkan adalah sebagai berikut:

$\mathrm{H}_{4}$ : Dana Bagi Hasil (DBH) berpengaruh positif dan signifikan terhadap pertumbuhan ekonomi di wilayah Sarbagita Provinsi Bali.

\section{METODE PENELITIAN}

Penelitian ini menggunakan pendekatan kuantitatif dengan bentuk asosiatif. Penelitian ini dilakukan di empat kabupaten/kota Provinsi Bali yaitu Denpasar, Badung, Gianyar dan Tabanan atau yang sering disebut wilayah Sarbagita guna mengetahui seberapa bresar pengaruh PAD, DAK, DAU dan DBH terhadap pertumbuhan ekonomi (PDRB). Penelitian ini menggunakan satu jenis dependent variabel (variabel terikat) dan empat jenis independent variabel (variabel bebas). Variabel bebas yang digunakan adalah Pendapatan Asli Daerah (PAD), Dana 
Lily Kusumawati, Pengaruh Pendapatan Daerah...

Alokasi Khusus (DAK), Dana Alokasi Umum (DAU), dan Dana Bagi Hasil (DBH) yang masing - masing diukur menggunakan data realisasi Kota Denpasar, Kabupaten Badung, Gianyar, dan Tabanan tahun 2012 - 2016. Variabel terikat yang digunakan yaitu pertumbuhan ekonomi. Pertumbuhan ekonomi tersebut diukur dengan PDRB berdasarkan atas dasar harga konstan tahun 2010 di wilayah Sarbagita Provinsi Bali.

Metode penentuan sampel yang digunakan adalah dengan metode sampling jenuh atau sensus, dimana semua anggota populasi dijadikan sampel. Populasi dan sampel yang digunakan adalah pendapatan daerah di wilayah Sarbagita Provinsi Bali tahun 2012 - 2016. Metode observasi non partisipan merupakan metode pengumpulan data yang diperoleh baik data kualitatif dan data kuantitatif. Data yaang diperoleh bersumber dari data sekunder yang diperoleh dari data yang telah dipublikasi oleh BPS Provinsi Bali yaitu karya ilmiah berupa jurnal, buku, dan skripsi, serta dokumen lainnya yang berkaitan dengan penelitian yang dilakukan.

Teknik analisis data yang digunakan ada 2 yaitu analisis statistik seskriptif dan analisis regresi linier berganda. Analisis statistik deskriptif bertujuan untuk menjawab rumusan masalah mengenai pengaruh keterkaitan pendapatan daerah dan pertumbuhan ekonomi di wilayah Sarbagita Provinsi Bali. Sedangkan, analisis regresi linear berganda berfungsi dalam memperoleh bayangan mengenai pengaruh $\mathrm{PAD}$, DAU, DAK dan $\mathrm{DBH}$ terhadap pertumbuhan ekonomi yang diukur melalui PDRB atas dasar harga konstan tahun 2010 di wilayah Sarbagita Provinsi Bali. Adapun model mengenai analisis regresi linear berganda yang digunakan ditunjukkan dalam sebuah persamaan sebagai berikut: 
$Y=\alpha+\beta_{1} X_{1}+\beta_{2} X_{2}+\beta_{3} X_{3}+\beta_{4} X_{4}+e$

Keterangan:

$\mathrm{Y}=$ Produk Domestik Regional Bruto

$\alpha=$ Bilangan Konstan

$\beta_{1}=$ Koefisien Regresi Rasio PAD

$\beta_{2}=$ Koefisien Regresi Rasio DAU

$\beta_{3}=$ Koefisien Regresi Rasio DAK

$\beta_{4}=$ Koefisien Regresi Rasio DBH

$\mathrm{X}_{1}=$ Rasio PAD

$\mathrm{X}_{2}=$ Rasio DAU

$\mathrm{X}_{3}=$ Rasio DAK

$\mathrm{X}_{4}=$ Rasio DBH

$\mathrm{e}=$ Residual Error

\section{HASIL DAN PEMBAHASAN}

PDRB Kabupaten Badung tahun 2012 - 2016 terus mengalami peningkatan secara fluktuatif seperti yang ditunjukkan pada Tabel 2.

Tabel 2. PDRB Menurut Lapangan Usaha Atas Dasar Harga Konstan Tahun 2010 Kabupaten Badung, 2012-2016

(Dalam Jutaan Rupiah)

\begin{tabular}{lccccc}
\hline \multicolumn{1}{c}{ Lapangan Usaha } & $\mathbf{2 0 1 2}$ & $\mathbf{2 0 1 3}$ & $\mathbf{2 0 1 4}$ & $\mathbf{2 0 1 5}$ & $\mathbf{2 0 1 6}$ \\
\hline $\begin{array}{l}\text { Pertanian, Kehutanan, } \\
\text { \& Perikanan }\end{array}$ & $1.954 .367,9$ & $1.982 .149,3$ & $2.087 .311,5$ & $2.182 .148,2$ & $2.243 .344,2$ \\
& & & & & \\
Pertambangan dan & $98.015,9$ & $105.140,1$ & $106.351,6$ & $102.076,4$ & $104.234,3$ \\
$\begin{array}{l}\text { Penggalian } \\
\text { Industri Pengolahan }\end{array}$ & $1.074 .565,5$ & $1.163 .278,2$ & $1.283 .499,3$ & $1.387 .237,8$ & $1.447 .932,0$ \\
$\begin{array}{l}\text { Konstruksi } \\
\text { Perdagangan Besar \& }\end{array}$ & $2.478 .052,5$ & $2.623 .076,0$ & $2.705 .925,4$ & $2.817 .432,2$ & $3.009 .188,4$ \\
$\begin{array}{l}\text { Eceran; Reparasi } \\
\text { Mobil \& Sepeda Motor }\end{array}$ & $1.749 .222,3$ & $1.905 .693,4$ & $2.073 .020,0$ & $2.238 .226,3$ & $2.359 .245,7$ \\
$\begin{array}{l}\text { Transportasi dan } \\
\text { Pergudangan }\end{array}$ & $4.552 .037,7$ & $4.826 .614,9$ & $4.958 .177,6$ & $5.093 .133,8$ & $5.552 .875,0$ \\
\hline Bersambung & & & & &
\end{tabular}


Lanjutan Tabel 2.

\begin{tabular}{lcrrrr}
\hline \multicolumn{1}{c}{ Lapangan Usaha } & $\mathbf{2 0 1 2}$ & $\mathbf{2 0 1 3}$ & $\mathbf{2 0 1 4}$ & $\mathbf{2 0 1 5}$ & \multicolumn{1}{c}{$\mathbf{2 0 1 6}$} \\
\hline $\begin{array}{l}\text { Penyediaan } \\
\text { Akomodasi \& Makan }\end{array}$ & $6.117 .806,9$ & $6.631 .284,5$ & $7.132 .961,5$ & $7.640 .246,9$ & $8.142 .314,5$ \\
$\begin{array}{l}\text { Minum } \\
\text { Informasi dan }\end{array}$ & $1.824 .268,4$ & $1.927 .366,1$ & $2.092 .928,0$ & $2.276 .899,0$ & $2.481 .239,4$ \\
Komunikasi & & & & & \\
Jasa Keuangan dan & $653.915,5$ & $737.528,2$ & $819.727,5$ & $890.634,6$ & $957.430,1$ \\
Asuransi & & & & & \\
Real Estat & $945.467,0$ & $1.010 .167,5$ & $1.115 .698,2$ & $1.202 .303,5$ & $1.264 .178,2$ \\
Jasa Perusahaan & $185.228,6$ & $202.083,0$ & $220.511,4$ & $236.098,9$ & $248.113,4$ \\
Administrasi & $999.984,2$ & $998.014,5$ & $1.122 .021,4$ & $1.229 .680,2$ & $1.324 .152,8$ \\
Pemerintah, & & & & & \\
Pertahanan \& Jaminan & & & & & \\
Sosial Wajib & & & & & \\
Jasa Pendidikan & $768.876,5$ & $873.738,8$ & $981.167,1$ & $1.062 .447,7$ & $1.137 .383,7$ \\
Jasa Kesehatan \& & $304.442,6$ & $343.019,6$ & $391.441,8$ & $432.650,2$ & $468.674,4$ \\
Kegiatan Sosial & $195.488,3$ & $203.367,3$ & $222.346,9$ & $240.596,0$ & $261.506,7$ \\
Jasa Lainnya & $\mathbf{2 4 . 0 2 7 . 6 5 1 , 2}$ & $\mathbf{2 5 . 6 6 6 . 5 3 1 , 6}$ & $\mathbf{2 7 . 4 5 8 . 0 6 0 , 1}$ & $\mathbf{2 9 . 1 8 0 . 4 7 9 , 4}$ & $\mathbf{3 1 . 1 6 0 . 5 8 4 , 6}$ \\
\hline PDRB & & & & \\
\hline Sumber: Kabupaten Badung dalam Angka & 2017 & & &
\end{tabular}

Berdasarkan Tabel 2, sektor yang memiliki kontribusi terbesar terhadap perekonomian Kabupaten Badung hingga tahun 2016 adalah sektor penyediaan akomodasi dan makan minum yaitu mencapai Rp 8.142.314,5 Juta. Sektor tersebut merupakan salah satu aktivitas produksi yang menjadi prioritas sumber pendapatan Kabupaten Badung. Sektor lain seperti sektor lapangan usaha transportasi dan pergudangan, perdagangan besar \& bceran; reparasi mobil \& sepeda motor, dan konstruksi juga menjadi prioritas sumber pendapatan Kabupaten Badung.

PDRB Kabupaten Gianyar tahun 2012-2016 terus mengalami peningkatan secara fluktuatif yang dapat dilihat pada Tabel 3. 
Tabel 3. PDRB Menurut Lapangan Usaha Atas Dasar Harga Konstan Tahun 2010 Kabupaten Gianyar, 2012-2016

(Dalam Juta rupiah)

\begin{tabular}{|c|c|c|c|c|c|}
\hline Lapangan Usaha & 2012 & 2013 & 2014 & 2015 & 2016 \\
\hline $\begin{array}{l}\text { Pertanian, } \\
\text { Kehutanan, \& } \\
\text { Perikanan }\end{array}$ & $1.772 .274,8$ & $1.804 .395,0$ & $1.870 .783,4$ & $1.949 .996,3$ & $1.973 .164,9$ \\
\hline $\begin{array}{l}\text { Pertambangan dan } \\
\text { Penggalian }\end{array}$ & $260.421,6$ & $280.506,0$ & $280.047,1$ & $256.986,5$ & $265.287,2$ \\
\hline $\begin{array}{l}\text { Industri } \\
\text { Pengolahan }\end{array}$ & $1.501 .771,7$ & $1.640 .968,4$ & $1.793 .255,7$ & $1.928 .535,6$ & $2.022 .979,9$ \\
\hline $\begin{array}{l}\text { Pengadaan Listrik } \\
\text { dan Gas }\end{array}$ & $13.381,0$ & $14.515,7$ & $14.917,6$ & $14.970,2$ & $16.960,9$ \\
\hline $\begin{array}{l}\text { Pengadaan Air, } \\
\text { Pengelolaan } \\
\text { Sampah, Limbah \& } \\
\text { Daur Ulang }\end{array}$ & $20.664,4$ & $21.876,2$ & $23.482,5$ & $23.871,4$ & $24.792,6$ \\
\hline Konstruksi & $1.544 .565,7$ & $1.641 .724,9$ & $1.671 .547,2$ & $1.732 .060,3$ & $1.837 .461,3$ \\
\hline $\begin{array}{l}\text { Perdagangan Besar } \\
\text { \& Eceran; Reparasi } \\
\text { Mobil \& Sepeda } \\
\text { Motor }\end{array}$ & $938.789,8$ & $1.027 .761,0$ & $1.104 .118,8$ & $1.189 .094,4$ & $1.278 .598,2$ \\
\hline $\begin{array}{l}\text { Transportasi dan } \\
\text { Pergudangan }\end{array}$ & $125.057,5$ & $133.163,6$ & $144.471,1$ & $150.549,5$ & $163.449,9$ \\
\hline $\begin{array}{l}\text { Penyediaan } \\
\text { Akomodasi \& } \\
\text { Makan Minum }\end{array}$ & $2.525 .457,3$ & $2.713 .859,3$ & 2.899.290,2 & $3.106 .769,3$ & $3.394 .590,0$ \\
\hline $\begin{array}{l}\text { Informasi dan } \\
\text { Komunikasi }\end{array}$ & $920.958,3$ & $977.032,7$ & $1.047 .158,6$ & $1.149 .421,7$ & $1.246 .320,3$ \\
\hline $\begin{array}{l}\text { Jasa Keuangan dan } \\
\text { Asuransi }\end{array}$ & $481.544,8$ & $546.922,6$ & $600.078,1$ & $635.393,0$ & $669.875,9$ \\
\hline Real Estat & $640.064,9$ & $686.696,3$ & $748.568,1$ & $785.713,5$ & $819.983,9$ \\
\hline Jasa Perusahaan & $139.646,5$ & $152.983,8$ & $164.763,1$ & $176.970,1$ & $191.531,8$ \\
\hline $\begin{array}{l}\text { Administrasi } \\
\text { Pemerintah, } \\
\text { Pertahanan \& } \\
\text { Jaminan Sosial } \\
\text { Wajib }\end{array}$ & $764.623,2$ & $766.275,3$ & $850.280,9$ & $919.456,3$ & $979.802,8$ \\
\hline Jasa Pendidikan & $268.997,7$ & $306.949,7$ & $340.205,9$ & $371.284,9$ & $396.327,9$ \\
\hline $\begin{array}{l}\text { Jasa Kesehatan \& } \\
\text { Kegiatan Sosial }\end{array}$ & $368.614,5$ & $417.041,7$ & $469.722,3$ & $513.030,9$ & $559.127,87$ \\
\hline Jasa Lainnya & $221.829,2$ & $231.724,9$ & $250.055,2$ & $269.213,0$ & $289.653,25$ \\
\hline PDRB & $12.508 .662,9$ & $13.364 .397,1$ & $14.272 .745,4$ & $15.173 .314,9$ & $16.129 .908,4$ \\
\hline
\end{tabular}

Sumber: Kabupaten Gianyar dalam Angka, 2017

Berdasarkan Tabel 4.2, sektor yang memiliki kontribusi terbesar terhadap perekonomian Kabupaten Gianyar hingga tahun 2016 adalah sektor penyediaan akomodasi dan makan minum yaitu mencapai Rp 3.394.590,0 juta. Sektor tersebut 
merupakan salah satu aktivitas produksi yang menjadi prioritas sumber pendapatan Kabupaten Gianyar. Sektor lain seperti sektor lapangan usaha pertanian, kehutanan, \& perikanan, industri pengolahan, konstruksi, perdagangan besar \& eceran; reparasi mobil \& sepeda motor dan informasi \& komunikasi juga menjadi prioritas sumber pendapatan Kabupaten Gianyar.

PDRB Kabupaten Tabanan tahun 2012-2016 terus mengalami peningkatan secara fluktuatif yang dapat dilihat pada Tabel 4.

\section{Tabel 4. PDRB Menurut Lapangan Usaha Atas Dasar Harga Konstan Tahun 2010 Kabupaten Tabanan, 2012-2016}

(Dalam Juta rupiah)

\begin{tabular}{|c|c|c|c|c|c|}
\hline Lapangan Usaha & 2012 & 2013 & 2014 & 2015 & 2016 \\
\hline $\begin{array}{l}\text { Pertanian, Kehutanan, } \\
\text { \& Perikanan }\end{array}$ & $2.520 .268,0$ & $2.581 .438,5$ & $2.673 .872,1$ & $2.726 .575,0$ & $2.868 .766,1$ \\
\hline $\begin{array}{l}\text { Pertambangan dan } \\
\text { Penggalian }\end{array}$ & $149.887,4$ & $162.129,6$ & $162.091,1$ & $156.343,8$ & $160.641,03$ \\
\hline Industri Pengolahan & $585.413,3$ & $639.107,6$ & $695.818,6$ & $771.128,6$ & $808.679,8$ \\
\hline $\begin{array}{l}\text { Pengadaan Listrik dan } \\
\text { Gas }\end{array}$ & $11.987,4$ & $13.043,9$ & $13.567,6$ & $13.460,6$ & $13.717,3$ \\
\hline $\begin{array}{l}\text { Pengadaan Air, } \\
\text { Pengelolaan Sampah, } \\
\text { Limbah \& Daur Ulang }\end{array}$ & $20.230,4$ & $21.507,3$ & $23.118,8$ & $23.573,1$ & $24.445,7$ \\
\hline Konstruksi & $1.078 .816,2$ & $1.151 .525,4$ & $1.174 .085,7$ & $1.255 .518,9$ & $1.343 .604,7$ \\
\hline $\begin{array}{l}\text { Perdagangan Besar \& } \\
\text { Eceran; Reparasi } \\
\text { Mobil \& Sepeda Motor }\end{array}$ & $855.403,5$ & $940.291,0$ & $1.011 .444,2$ & $1.105 .066,7$ & $1.186 .417,8$ \\
\hline $\begin{array}{l}\text { Transportasi dan } \\
\text { Pergudangan }\end{array}$ & $178.684,0$ & $191.052,9$ & $207.718,4$ & $214.611,4$ & $233.058,4$ \\
\hline $\begin{array}{l}\text { Penyediaan } \\
\text { Akomodasi \& Makan } \\
\text { Minum }\end{array}$ & $1.892 .207,9$ & $2.050 .685,0$ & $2.189 .285,6$ & $2.310 .918,9$ & $2.438 .015,0$ \\
\hline $\begin{array}{l}\text { Administrasi } \\
\text { Pemerintah, } \\
\text { Pertahanan \& Jaminan } \\
\text { Sosial Wajib }\end{array}$ & $897.151,5$ & $902.890,8$ & $1.003 .277,0$ & $1.086 .304,4$ & $1.154 .801,7$ \\
\hline
\end{tabular}


Lanjutan Tabel 4.

\begin{tabular}{lcrrrr}
\hline \multicolumn{1}{c}{ Lapangan Usaha } & $\mathbf{2 0 1 2}$ & $\mathbf{2 0 1 3}$ & \multicolumn{1}{c}{$\mathbf{2 0 1 4}$} & \multicolumn{1}{c}{$\mathbf{2 0 1 5}$} & \multicolumn{1}{c}{$\mathbf{2 0 1 6}$} \\
\hline Jasa Pendidikan & $166.284,3$ & $190.546,9$ & $211.487,4$ & $236.334,2$ & \multicolumn{1}{c}{$255.736,5$} \\
Jasa Kesehatan \& & $215.096,7$ & $244.384,1$ & $275.640,2$ & $310.429,8$ & $334.490,8$ \\
Kegiatan Sosial & & & & & \\
Jasa Lainnya & $194.354,5$ & $203.882,7$ & $220.318,9$ & $241.638,5$ & $260.341,8$ \\
PDRB & $\mathbf{1 0 . 5 0 0 . 4 6 2 , 3}$ & $\mathbf{1 1 . 1 7 8 . 1 9 0 , 8}$ & $\mathbf{1 1 . 9 0 8 . 3 0 2 , 1}$ & $\mathbf{1 2 . 6 5 1 . 3 9 8 , 6}$ & $\mathbf{1 3 . 4 2 6 . 0 1 7 , 7}$ \\
\hline
\end{tabular}

Sumber: Kabupaten Tabanan dalam Angka, 2017

Berdasarkan Tabel 4, sektor yang memiliki kontribusi terbesar terhadap perekonomian Kabupaten Tabanan hingga tahun 2016 adalah sektor pertanian, kehutanan, dan perikanan yaitu mencapai Rp 2.868.766,1 juta. Sektor tersebut merupakan salah satu aktivitas produksi yang menjadi prioritas sumber pendapatan Kabupaten Tabanan. Sektor lain seperti sektor lapangan usaha penyediaan akomodasi dan makan minum, konstruksi, perdagangan besar \& bceran; reparasi mobil \& sepeda motor, dan administrasi pemerintah, pertahanan \& jaminan sosial wajib juga menjadi prioritas sumber pendapatan Kabupaten Tabanan.

PDRB Kota Denpasar tahun 2012 - 2016 terus mengalami peningkatan secara fluktuatif seperti yang ditunjukkan pada Tabel 5 .

Tabel 5 PDRB Menurut Lapangan Usaha Atas Dasar Harga Konstan Tahun 2010 Kota Denpasar, 2012-2016

\begin{tabular}{lccccc} 
& & & \multicolumn{2}{c}{ (Dalam Juta rupiah) } \\
\hline Lapangan Usaha & $\mathbf{2 0 1 2}$ & $\mathbf{2 0 1 3}$ & $\mathbf{2 0 1 4}$ & $\mathbf{2 0 1 5}$ & $\mathbf{2 0 1 6}$ \\
\hline Pertanian, & $1.784 .077,7$ & $1.827 .499,2$ & $1.983 .619,7$ & $1.976 .250,0$ & $2.001 .372,9$ \\
Kehutanan, \& & & & & & \\
Perikanan & & & & & \\
Konstruksi & $2.378 .320,6$ & $2.498 .338,9$ & $2.526 .388,3$ & $2.718 .740,0$ & $2.898 .343,4$ \\
Perdagangan Besar & $2.181 .524,2$ & $2.358 .611,5$ & $2.515 .109,7$ & $2.756 .330,0$ & $2.934 .326,1$ \\
\& Eceran; & & & & & \\
Reparasi Mobil \& & & & & & \\
Sepeda Motor & & & & & \\
\hline Bersambung & & & & &
\end{tabular}


Lanjutan Tabel 5.

\begin{tabular}{|c|c|c|c|c|c|}
\hline Lapangan Usaha & 2012 & 2013 & 2014 & 2015 & 2016 \\
\hline $\begin{array}{l}\text { Transportasi dan } \\
\text { Pergudangan }\end{array}$ & $745.033,6$ & $789.100,7$ & $856.361,7$ & $908.220,0$ & $974.724,4$ \\
\hline $\begin{array}{l}\text { Penyediaan } \\
\text { Akomodasi \& } \\
\text { Makan Minum }\end{array}$ & $5.573 .797,3$ & $5.989 .052,1$ & $6.318 .390,2$ & $6.564 .850,0$ & $6.986 .846,5$ \\
\hline $\begin{array}{l}\text { Jasa Keuangan dan } \\
\text { Asuransi }\end{array}$ & $1.391 .678,9$ & $1.557 .298,7$ & $1.696 .853,4$ & $1.819 .420,0$ & $1.964 .015,3$ \\
\hline Real Estat & $1.126 .169,1$ & $1.194 .073,9$ & $1.292 .791,0$ & $1.414 .790,0$ & $1.506 .061,1$ \\
\hline Jasa Perusahaan & $439.983,1$ & $476.363,1$ & $509.545,9$ & $547.390,0$ & $590.790,9$ \\
\hline $\begin{array}{l}\text { Administrasi } \\
\text { Pemerintah, } \\
\text { Pertahanan \& } \\
\text { Jaminan Sosial } \\
\text { Wajib }\end{array}$ & $1.389 .418,5$ & $1.376 .123,4$ & $1.516 .580,5$ & $1.616 .260,0$ & $1.752 .064,4$ \\
\hline Jasa Pendidikan & $2.414 .009,6$ & $2.722 .354,0$ & $2.996 .744,5$ & $3.238 .730,0$ & $3.504 .726,1$ \\
\hline $\begin{array}{l}\text { Jasa Kesehatan \& } \\
\text { Kegiatan Sosial }\end{array}$ & 483.084 .100 & 540.153 .000 & 604.239 .300 & 680.790 .000 & 742.789 .040 \\
\hline Jasa Lainnya & $358.014,5$ & $369.608,1$ & $396.127,7$ & $433.280,0$ & 457.279 .3 \\
\hline PDRB & 23.397.173,9 & $25.026 .379,3$ & 26.777.481,9 & 28.433.250,0 & $30.291 .024,3$ \\
\hline
\end{tabular}

Sumber: Kota Denpasar Dalam Angka, 2017

Berdasarkan Tabel 5, sektor yang memiliki kontribusi terbesar terhadap perekonomian Kota Denpasar hingga tahun 2016 adalah sektor penyediaan akomodasi dan makan minum yaitu mencapai Rp 6.986.846.460 juta. Sektor tersebut merupakan salah satu aktivitas produksi yang menjadi prioritas sumber pendapatan Kota Denpasar. Sektor lain seperti sektor lapangan usaha konstruksi, perdagangan besar \& eceran; reparasi mobil \& sepeda motor, industri pengolahan dan jasa pendidikan juga menjadi prioritas sumber pendapatan Kota Denpasar.

Jumlah data dalam penelitian ini adalah sebanyak 20 pengamatan yang diperoleh dari sampel sebanyak 4 kabupaten/kota dengan 5 tahun pengamatan. Hasil analisis deskriptif dalam penelitian ini dapat dilihat pada Tabel 6 sebagai berikut. 
Tabel 6. Hasil Statistik Deskriptif

\begin{tabular}{lrrrrr}
\hline & N & Minimum & Maximum & \multicolumn{1}{c}{ Mean } & \multicolumn{1}{l}{$\begin{array}{l}\text { Std. } \\
\text { Deviation }\end{array}$} \\
\hline PAD & 20 & 12,12 & 15,09 & 13,3878 & 0,92140 \\
DAU & 20 & 12,57 & 13,62 & 13,2023 & 0,30970 \\
DAK & 20 & 6,29 & 12,44 & 9,7592 & 1,95832 \\
DBH & 20 & 9,77 & 11,99 & 10,6769 & 0,64601 \\
PDRB & 20 & 24,55 & 49,46 & 33,3010 & 7,72456 \\
Valid N (listwise) & 20 & & & & \\
\hline \multicolumn{2}{l}{ Sumber: Data diolah, 2017} & & & &
\end{tabular}

Analisis regresi linier berganda dalam penelitian ini telah dilakukan dan diperoleh hasil yang dapat dilihat pada Tabel 7 sebagai berikut.

Tabel 7. Hasil Analisis Regresi Linier Berganda

\begin{tabular}{|c|c|c|c|c|c|}
\hline Model & $\begin{array}{l}\text { Unstandardi } \\
\text { Coefficients } \\
B\end{array}$ & Std. Error & $\begin{array}{l}\text { Standardized } \\
\text { Coefficients } \\
\text { Beta }\end{array}$ & $t$ & Sig. \\
\hline (Constant) & 18,390 & 31,984 & & 0,575 & 0,574 \\
\hline PAD & 8,303 & 0,602 & 0,990 & 13,784 & 0,000 \\
\hline DAU & $-5,907$ & 1,961 & $-0,237$ & $-3,013$ & 0,009 \\
\hline DAK & 0,677 & 0,208 & 0,172 & 3,254 & 0,005 \\
\hline DBH & $-2,328$ & 0,545 & $-0,195$ & $-4,274$ & 0,001 \\
\hline
\end{tabular}

Sumber: Data diolah, 2017

Berdasarkan hasil analisis regresi linier berganda yang dapat dilihat pada Tabel 7, maka persamaan regresi yang digunakan dalam penelitian ini dapat ditulis sebagai berikut:

$$
\mathrm{Y}=18,390+8,303 \mathrm{X}_{1}-5,907 \mathrm{X}_{2}+0,677 \mathrm{X}_{3}-2,328 \mathrm{X}_{4}+\mathrm{e}
$$

Nilai konstan 18,390 berarti bahwa jika PAD $\left(\mathrm{X}_{1}\right)$, DAU $\left(\mathrm{X}_{2}\right)$, DAK $\left(\mathrm{X}_{3}\right)$, dan DBH $\left(\mathrm{X}_{4}\right)$ diasumsikan tidak mengalami perubahan, maka nilai PDRB (Y) adalah sebesar 18,390 satuan. Nilai koefisien regresi PAD $\left(\mathrm{X}_{1}\right)$ adalah sebesar 8,303 berarti bahwa jika PAD $\left(\mathrm{X}_{1}\right)$ naik sebesar satu satuan, sementara DAU $\left(\mathrm{X}_{2}\right)$, DAK $\left(\mathrm{X}_{3}\right)$, dan DBH $\left(\mathrm{X}_{4}\right)$ diasumsikan tetap, maka PDRB (Y) akan meningkat sebesar 8,303 satuan. Nilai koefisien regresi DAU $\left(\mathrm{X}_{2}\right)$ adalah sebesar $-5,907$ berarti bahwa jika DAU $\left(\mathrm{X}_{2}\right)$ naik sebesar satu satuan, sementara PAD $\left(\mathrm{X}_{1}\right)$, DAK $\left(\mathrm{X}_{3}\right)$, dan $\mathrm{DBH}\left(\mathrm{X}_{4}\right)$ diasumsikan tetap, maka PDRB $(\mathrm{Y})$ akan menurun sebesar 
5,907 satuan. Nilai koefisien regresi DAK $\left(\mathrm{X}_{3}\right)$ adalah sebesar 0,677 berarti bahwa jika PAD $\left(\mathrm{X}_{1}\right)$ naik sebesar satu satuan, sementara PAD $\left(\mathrm{X}_{1}\right)$, DAU $\left(\mathrm{X}_{2}\right)$, dan $\mathrm{DBH}\left(\mathrm{X}_{4}\right)$ diasumsikan tetap, maka PDRB (Y) akan meningkat sebesar 0,677 satuan. Nilai koefisien regresi DBH $\left(\mathrm{X}_{4}\right)$ adalah sebesar -2,328 berarti bahwa jika DBH $\left(\mathrm{X}_{4}\right)$ naik sebesar satu satuan, sementara PAD $\left(\mathrm{X}_{1}\right), \mathrm{DAU}\left(\mathrm{X}_{2}\right)$, dan DAK $\left(\mathrm{X}_{3}\right)$ diasumsikan tetap, maka PDRB (Y) akan menurun sebesar 2,328 satuan.

Hasil uji pengaruh variabel PAD terhadap pertumbuhan ekonomi melalui PDRB diperoleh koefisien regresi sebesar 8,303 dan nilai signifikasinya adalah sebesar 0,000 lebih kecil dari 0,05. Hal ini menunjukkan bahwa variabel PAD berpengaruh signifikan terhadap pertumbuhan ekonomi dan nilai koefisien regresi pada variabel PAD membuktikan bahwa adanya pengaruh positif PAD terhadap pertumbuhan ekonomi. Maka, dapat dikatakan bahwa $\mathrm{H}_{1}$ diterima dan $\mathrm{H}_{0}$ ditolak. Hasil penelitian ini sesuai dengan penelitian yang dilakukan oleh Putri (2015). Hasil penelitian ini berarti bahwa semakin tinggi PAD yang diperoleh masingmasing kabupaten di wilayah Sarbagita, maka akan semakin tinggi pula pertumbuhan ekonomi yang ada di wilayah Sarbagita Provinsi Bali.

Hasil uji pengaruh variabel DAU terhadap pertumbuhan ekonomi melalui PDRB diperoleh koefisien regresi sebesar -5,907 dan nilai signifikasinya adalah sebesar 0,009 lebih kecil dari 0,05. Hal ini menunjukkan bahwa variabel DAU berpengaruh signifikan terhadap pertumbuhan ekonomi, tetapi nilai koefisien regresi pada variabel DAU membuktikan bahwa adanya pengaruh negatif DAU terhadap pertumbuhan ekonomi. Maka, dapat dikatakan bahwa $\mathrm{H}_{2}$ ditolak dan $\mathrm{H}_{0}$ diterima. Hasil penelitian ini berarti bahwa semakin tinggi DAU yang diterima 
masing-masing kabupaten di wilayah Sarbagita, maka pertumbuhan ekonomi yang ada di wilayah Sarbagita Provinsi Bali akan menurun. Hasil penelitian ini tidak berhasil membuktikan penelitian yang dilakukan oleh Mawarni dkk., (2013) dan Panji (2016) yang menemukan DAU memiliki hubungan positif dan signifikan terhadap pertumbuhan ekonomi. Ini berarti bahwa semakin besar jumlah DAU yang diterima, maka akan dapat mengurangi laju pertumbuhan ekonomi. Hal ini kemungkinan disebabkan karena penyerapan DAU masih belum signifikan. Selain itu, kemungkinan dapat disebabkan karena jumlah DAU yang diterima dipengaruhi oleh kenaikan PAD yang ada di wilayah tersebut.

Hasil uji pengaruh variabel DAK terhadap pertumbuhan ekonomi melalui PDRB diperoleh koefisien regresi sebesar 0,677 dan nilai signifikasinya adalah sebesar 0,005 lebih kecil dari 0,05. Hal ini menunjukkan bahwa variabel DAK berpengaruh signifikan terhadap pertumbuhan ekonomi dan nilai koefisien regresi pada variabel DAK membuktikan bahwa adanya pengaruh negatif DAK terhadap pertumbuhan ekonomi. Maka, dapat dikatakan bahwa $\mathrm{H}_{3}$ diterima dan $\mathrm{H}_{0}$ ditolak. Hasil penelitian ini berarti bahwa semakin tinggi DAK yang diterima masingmasing kabupaten di wilayah Sarbagita, maka pertumbuhan ekonomi yang ada di wilayah Sarbagita Provinsi Bali akan meningkat pula. Hal ini disebabkan karena DAK yang diterima secara keseluruhan telah digunakan untuk pembangunan daerah dan peningkatan pertumbuhan ekonomi daerah. Hasil penelitian ini berhasil membuktikan penelitian yang dilakukan oleh Santosa (2013).

Hasil uji pengaruh variabel DBH terhadap pertumbuhan ekonomi melalui PDRB diperoleh koefisien regresi sebesar -2,328 dan nilai signifikasinya adalah 
sebesar 0,001 lebih kecil dari 0,05. Hal ini menunjukkan bahwa variabel DBH berpengaruh signifikan terhadap pertumbuhan ekonomi, tetapi nilai koefisien regresi pada variabel $\mathrm{DBH}$ membuktikan bahwa adanya pengaruh negatif $\mathrm{DBH}$ terhadap pertumbuhan ekonomi. Maka, dapat dikatakan bahwa $\mathrm{H}_{4}$ ditolak dan $\mathrm{H}_{0}$ diterima.

Hasil penelitian ini berarti bahwa semakin tinggi DBH yang diterima masing-masing kabupaten di wilayah Sarbagita, maka akan berdampak pada penurunana pertumbuhan ekonomi yang ada di wilayah Sarbagita Provinsi Bali. Hasil penelitian ini tidak berhasil membuktikan penelitian yang dilakukan oleh Santosa (2013) dan Dewi (2015) yang menemukan DBH berpengaruh positif dan signifikan terhadap pertumbuhan ekonomi. Ini berarti bahwa semakin besar jumlah DBH yang diterima, maka akan dapat mengurangi laju pertumbuhan ekonomi. Hal ini disebabkan karena realisasi DBH yang diterima secara keseluruhan kurang berkontribusi untuk pembangunan daerah dan peningkatan pertumbuhan ekonomi daerah. Jika ada penggunaan DBH untuk peningkatan daerah itu hanya sebagian kecil dan tidak berdampak pada pertumbuhan ekonomi daerah.

\section{SIMPULAN DAN SARAN}

Kesimpulan yang dapat diperoleh dari hasil penelitian adalah Pendapatan Asli Daerah (PAD) berpengaruh positif signifikan terhadap pertumbuhan ekonomi di wilayah Sarbagita Provinsi Bali. Hasil tersebut membuktikan bahwa semakin tingi PAD yang ada di daerah tersebut, menyebabkan laju pertumbuhan ekonomi 
daerahnya juga semakin tinggi. Dana Alokasi Umum (DAU) dan Dana Bagi Hasil (DBH) berpengaruh negatif signifikan terhadap pertumbuhan ekonomi di wilayah Sarbagita Provinsi Bali. Hal tersebut membuktikan bahwa apabila semakin tingginya pengalokasian realisasi DAU yang diberikan dari pemerintah pusat dapat mengurangi laju pertumbuhan ekonomi daerah yang disebabkan karena DAU secara keseluruhan tidak digunakan untuk peningkatan ekonomi daerah.

Dana Alokasi Khusus (DAK) memiliki pengaruh yang positif signifikan terhadap pertumbuhan ekonomi di wilayah Sarbagita Provinsi Bali. Hasil tersebyt menandakan bahwa pemberian pengalokasian realisasi DAK oleh pemerintah pusat yang semakin tinggi dapat meningkatkan laju pertumbuhan ekonomi daerah. Dana Bagi Hasil (DBH) memiliki pengaruh yang negatif signifikan terhadap pertumbuhan ekonomi di wilayah Sarbagita Provinsi Bali. Hal ini menunjukkan bahwa peorlehan DBH oleh pemerintah daerah yang semakin tinggi DBH yang maka akan dapat memperlambat laju pertumbuhan ekonomi daerah yang disebabkan karena secara keseluruhan DBH kurang berkontribusi untuk peningkatan daerahnya.

Saran yang bisa diberikan adalah sebagai Pemerintah daerah diharapkan lebih fokus dalam mendalami dan mengembangkan potensi yang ada di daerah masing-masing kabupaten/kota di wilayah Sarbagita Provinsi Bali antara lain a) upaya yang dapat dilakukan Pemerintah Kabupaten Badung dalam meningkatkan perekonomian daerah melalui optimalisasi potensi ekonomi daerah adalah dengan cara menjaga kelestarian lingkungan dan menunjang pariwisata khususnya sektor penyedia akomodasi serta makan dan minum yang merupakan sektor unggulan di 
Lily Kusumawati, Pengaruh Pendapatan Daerah...

Kabupaten Badung, yaitu perdagangan besar dan eceran, perhotelan serta restoran. b) upaya yang dapat dilakukan Pemerintah Kabupaten Gianyar dalam meningkatkan perekonomian daerah melalui optimalisasi potensi ekonomi daerah adalah dengan cara mengembangkan ekonomi berbasis kreatif serta sebuah usaha kerakyatan ekonomi berbasis pada produk unggulan daerah (one village one product atau OVOP) yaitu sektor penyediaan akomodasi dan makan minum yang merupakan sektor unggulan di Kabupaten Gianyar, yaitu perdagangan besar dan eceran, perhotelan serta restoran. c) upaya yang dapat dilakukan Pemerintah Kabupaten Tabanan dalam meningkatkan perekonomian daerah melalui optimalisasi potensi ekonomi daerah adalah dengan cara meningkatkan memfasilitasi berkembangnya agribisnis dan agrowisata melalui pemanfaatan sumber daya secara optimal serta berkelanjutan pada sektor pertanian, perikanan dan kehutananyang merupakan sektor unggulan di Kabupaten Tabanan, seperti petani tanaman pangan antara lain: padi dan palawija. d) upaya yang dapat dilakukan Pemerintah Kota Denpasar dalam meningkatkan perekonomian daerah melalui optimalisasi potensi ekonomi daerah adalah dengan cara meningkatkan produktivitas SDM, kualitas tenaga kerja, dan kemampuan penguasaan teknologi melalui sektor penyediaan akomodasi dan makan minum yang merupakan sektor unggulan di Kota Denpasar, yaitu perdagangan besar dan eceran, perhotelan serta restoran.

Saran lainnya yang dapat disampaikan adalah kepada pemerintah masing masing daerah di wilayah Sarbagita Provinsi Bali diharapkan lebih mengoptimalkan penggunaan DAU dan DBH untuk mendanai setiap kebutuhan 
daerahnya agar dapat meningkatkan laju pertumbuhan ekonomi daerahnya masing - masing. Sedangkan saran bagi penelitian selanjutnya diharapkan mampu menambahkan variabel lain seperti Belanja Daerah dan memperpanjang rentang periode penelitian sebagai salah satu cara mengembangkan penelitian.

\section{REFERENSI}

Andriyani, Sri dan Suyana Utama. 2014. Analisis Pusat Pertumbuhan di Karangasem. E - Jurnal Ekonomi Pembangunan Universiitas Udayana, 4 (4), 220-229.

Achmad, Kuncoro. 2001 Cara Menggunakan dan Memaknaii Analisis Asumsi Klasik. CetakanPertama. Bandung: ALFABETA

Aprisa, Lintanti Fajar. 2013 Pengaruh Desentralisasi Fiskal terhadap Perumbuhan Ekonomi Daerah dan KetimpanganEkonomi. Dipenogoro Journal of Economics, 2(1).

Aristovnik, A. 2012 Fiscal Decentralization Eastern Europe: Trend and selected Issu. Transilvanian Review of Administrative Science. (37/E), 5-22.

Arsad, Lincolyn. 2015. Ekonomi Pembangunan Edisi Kelima. Yogyakarta: UPP STIM YKPN.

Aulia, Nely. 2014. Hubungan Desentraliisasi Fiskal Terhadap Pertumbuhan Ekonomi, Tingkat Kemiskinan, dan Kesenjangan Pendapatan di Provinsi Jawa Tengah Tahun 2012. Economics Development Analysis Journal (EDAJ), 3 (2).

Badan Perencanaan Pembangunan Daerah Provinsi Bali. 2016. Perbandingan Pertumbuhan Ekonomi Bali dan Nasional Tahun 2010 - 2015 (persen).

Badan Pusat Statistik 2016. Bali dalam angka 2016. Denpasar: BPS Bali.

Badan Pusat Statistik. 2017. Kabupaten Badung dalam angka 2017. Denpasar: BPS Bali.

-----. 2017. Kabupaten Gianyar Dalam Angka 2017. Denpasar: BPS Bali.

-----. 2017. Kabupaten Tabanan Dalam Angka 2017. Denpasar: BPS Bali.

-----. 2017. Kota Denpasar Dalam Angka 2017. Denpasar: BPS Bali.

2017. Statistik Keuangan Pemerintah Kabupaten/Kota Se-Provinsi Bali 2012 - 2016. Denpasar: BPS Bali. 
Barimbing, Yesika Resiana dan Ni Luh Karmin. 2015 Pengaruh PAD, Tenaga Kerja, dan Investasi terhadap Pertumbuhan Ekonomi di Provinsi Bali. Skripsi Sarjana Jurusan Ekonomi Pembangunan pada Fakultas Ekonomi dan Bisnis Universitas Udayana, Bali.

Chinweoke, N; Ray. N. and Paschal, N. O. 2014 Impact of Government Expenditure on Nigeria's Economic Growth (1992-2011). The Macrotheme Review: A Multidisciplinary Journal of Global Macro Trends, 3 (7), 79-87.

Chude, N. P. and Chude, D. I. 2013 Impact of Goverment Expenditur on Economics Growths Nigeria. International Journals of Busines and Management Review, 1 (4), 64-71.

Devkota K. L. 2014 Impact of Fiscal Decentralization on Economics Growths in The District of Nepal. International Center for Publics Policy Working Paper, 14-20 March 2014.

Dewi,Ni Wayan Nuryanti. dan Made Kembar Sri Budhi. 2015. Pengaruih Pendapatan Asli Daerah dan Dana Bagi Hasil Terhadap Pertumbuhan Ekonomi Melalui Belanja Langsung di Provinsi Bali. E-Jurnal Ekonomi Pembangunan Universitas Udayana, 4 (11), 1391-1420.

Dewi, Sakita Laksmi dan I B.P. Purbandharmaja. 2013.Pengaruh PAD, PMA dan Inflasii terhadap Pertumbuhan Ekonomi di Provinsi Bali. E - Jurnal Ekonomi Pembangunan Universitas Udayana, 5 (11), 502-512.

Edogbanya. Adejoh, and J.G. Sule. 2013. Revenu Generations: It is impact on Government Developmental Effort (A Study of Selected Local Council in Kogi East Senatorial District). Global Journal of Management and Business research Administration and Management, 13 (4), 1-15.

Faridi, Muhammad Zahir. 2011. Contribution of Fiscal Decentralization to Economics Growths: Evidence from Pakistan. Paksitan Journal of Social Science (PJSS), 31 (1), 1-13

Fauzini, Wulan. 2013. Analisa Pengaruh Pendapatan AsliDaerah (PAD), Dana Alokasi Khusus (DAK), Dana Bagi Hasiil (DBH) Pajak atau Bukan Pajak terhadap Pertumbuhan Ekonomi di Kabupaten/Kota Propinsi di Jawa Tengah tahun 2003 - 2011. Skripsi. http://repository.uinjkt.ac.id/. Diakses tanggal 1 Juni 2017.

Hariyadi, Eko dan Nyoman Mahendra Yasa. 2014. Pengaruh PAD terhadap PDRB dan Pertumbuhan Ekonomi Kabupaten/Kota Provinsi Bali. E - Jurnal Ekonomi Pembangunan Universitas Udayana, 3 (12), 586-593.

Jaya, I P.N. Panji Kartika dan A.N.B. Dwiandra. 2014. Pengaruh Pendapatan Asli Daerah pada Belanja Modal dengan Pertumbuhan Ekonomi sebagai Variabel Pemoderasi. E-Jurnal Akuntansi Universitas Udayana, 7 (1), 7992. 
Jumadi, Pudjiharjo M., G. Maski, dan M. Khusaini. 2013. The Impact of Fiscal Decentralization on Local Economics Developmentt East Java. IOSR Journal of Humanity and Social Science (IOSR - JHS), 13 (1).

Norregaard, John. 2013. Taxing Immovablee Property: Revenue Potency and Impelmentation Challenges. IMF Working Paper. http://citeseerx.ist.psu.edu/viewdoc/download?doi=10.1.1.358.913\&rep=re pl\&type $=p d f$. Diakses 17 Juni 2017

Nurcholis, Hanif. 2005. Teori dan Praktik Pemerintah dan Otonomi Daerah.Grasindo: Jakarta.

Nurlis. 2016. The Factor Afecting of the Capital Expenditure Alocation Case: The Local Goverment of Indonesia. Research Journasl of Finances and Accounting, 7(1).

Kuznets dalam Jhingan. 2000. Teori pertumbuhan ekonomi.

Mardiasmo. 2002. Otonomi daan Manajmen Keuangan Daerah. Yogyakarta: CV Andy Offset

Mahmudi. 2009. Manajemen keuangan daerah. Jakarta:Erlangga

Mawarni, dan Darwanies Syukri Abdullah.2013. Pengaruh Pendapatan asli Daerah dan Dana Alokasi Umum terhadap Belanja Modal serta Dampaknya terhadap Pertumbuhan Ekonomi Daerah (Studi pada Kabupaten dan Kota di Aceh). Jurnal Akuntansi, 2 (2), 80-90.

Panji, I P. Barat. dan I G.B. Indrajaya. 2016. Pengaruh DanaPerimbangan terhadap Pertumbuhan Ekonomi dan Tingkat Kemiskinan Provinsi Bali. E Jurnal Ekonomi Pembangunan Universitas Udayana, 5 (3), 316- 337.

Parsiyo dan Widia Iswara Madya.2013. Indikatorr Keberhasilan Pembangunan. PPMKP Bogor, Jawa Barat.

Pradita, Rizanda Ratna.2013. Pengaruh Pendapatan Asli Daerah dan Dana Alokasi Umuum terhadap Pertumbuhan ekonomi Provinsi Jawa Timur. jurnal Akuntansi Universitas Negeri Surabaya, 1 (2).

Putri, Zuwesti Eka. 2015. Analisis Pengaruh Pendapatan Aslii Daerah (PAD), Dana Alokasi Umum (DAU) dan Inflasi terhadap Pertumbuhan Ekonomi Di Kabupaten/Kota Provinsi Jawa Tengah. Jurnal Bisnis dan Manajemen. UIN Syarif Hidayatullah Jakarta, 5 (2).

Rahyuda, I K., I G.W. Murjana Yasadan I Nyoman Yuliarmi. 2004. Metodologi Penelittian. Denpasar:Universitas Udayana Press.

Santosa, Budi.2013. PengaruhPendapatan Asli Daerah daan Dana Perimbangan Daerah terhadap Pertumbuhan, Pengangguran, dan Kemiskinan di 33 Provinsi Indonesia. Jurnal Keuangan dan Bisnis, 5 (2). 
Saragih, Juli Panglima. 2003. Desentralisasi Fiscal daan Keuangan Daerah dalam Otonomii. Jakarta:Ghalia Indonesia.

Setyawan, Hery Budi. 2013. Keefektivan Transfer Pusat terhadap Perekonomian Provinsi Lampung. Jurnal BPPK, 6 (1), 29-40.

Sukirno, Sadono. 2010. Makroekonomi Teori Pengantar. Jakarta: Raja Grafindo Persada.

Sumarsono, Dr. Hadi. dan Dr. Farida Rahmawati. 2017. The Phenomenon Flypaper Effect in Balanced Funds, Regional Revenue and Surplus Budget Funding of Economic Growth and Regional Expenditure in Districts/ City East Java Province. IOSR Journal Of Economics and Finance (IOSR-JEF). $8(1), 42-52$.

Supartoyo, Yesi Hendriani dan Jen Tatuh. 2013. "The Economic Growth and The Regional Characteristics: The Case of Indonesia". Buletin Ekonomi Moneter dan Perbankan, 16 (1).

Syakier, Husin. 2012. Pengaruh Belanja langsung, Pendapatan Asli Daerah, Dana Alokasi Umum, dan Dana Alokasi Khusus Terhadap Pertumbuhan ekonomi (Study Empiris di Wilayah Karesidenan Surakarta). Skripsi Sarjana Jurusan Akuntansi pada Universitas Muhammadiyah Surakarta.

Taras, Tyasani dan Luh Gede Sri Artini. 2017. Analisis Pendapatan AsliDaerah (PAD) dalam Upaya Pelaksanaan Otonomi Daerah KabupatenBadung Bali. E-Jurnal Manajemen Universitas Udayana, 6 (5), 2360:2387.

Ulfi, Maryati dan Endrawati.2010. Politehnik Negeri Padang Pengaruh Pendapatan Asli Daerah (PAD), Dana Alokasi Umum (DAU) Dan Dana Alokasi Khusus (DAK) Tehadap Pertumbuhan Ekonomi: Studi Kasus Sumatera Barat. Jumal Akuntansi \& Manajemen, 5 (2), 68-84.

Undang - Undang Nomor 5 tahun 1999 Tentang Pokok - pokok Pemerintahan Daerah

Undang - Undang Nomor 22 tahun 1999 Tentang Pemerintahan Daerah

Undang - Undang Nomor 23 tahun 2014 Tentang Pemerintah Daerah

Undang - undang Nomor 25 tahun 2004 tentang SistemPerencanaan Pembangunan Nasional

Undang - Undang Nomor 32 Tahun 2004 tentang PemerintahDaerah

Undang - Undang Nomor 33 Tahun 2004 tentang Periimbangan Keuangan Daerah Pemerntah Pusat dan Pemerintahan Daerah.

Undang-Undang Nomor 34 Tahun 2000 Tentang Pajak Daerah dan Retribusi Daerah 
Wandira, Arbi Gugus. 2013. Pengaruh DAU, PAD, DAK, dan DBH terhadap Pengalokasiian Belanja Modal. Jurnal Akuntansi Universitas Negeri Semarang, 2 (1), 44-51.

Wijayanti, Ni Kadek Herni. dan I.B. Darsana. 2015. Pengaruh Pendapatan Asli Daerah dan Dana Alokasi Umum terhadap Kesejahteraan Masyarakat Melalui Pertumbuhan Ekonomi. E-Jurnal Ekonomi Pembangunan Universitas Udayana. 4 (9), 1164-1193.

Williantara, Gede Ferdi dan I G.N. Budiasih. 2016. PengaruhPendapatan Asli Daerah, Dana Alokasi Umum, Dana Alokasi Khusus, dan Dana Bagi Hasil Pada Indeks Pembangunan Manusia. E-Jurnal Akuntansi Universitas Udayana, 16 (3), 2044-2070.

Wulandari, Pande Paramita dan Ayuningsari. 2014. Analisa Variabel yang Mempengaruhii Pendapatan Asli Daerah Provinsi Bali. E-Jurnal Ekonomi Pembangunan Universitas Udayana, 2 (11), 530-539.

Zakaria, Syawal. 2013. The Iimpact of Fiscals Decentrlization toward Regional Inequalitiess in Eastern Regions of Indonesia. Journals Economic and Sustainable Development, 4 (10). 